\title{
The new "Uncle Tom"'s of Our New Media.
}

\author{
Camille Akmut
}

Working paper.

\begin{abstract}
In his unfinished manuscript, James Baldwin created what can be considered the premise of a complete and general theory of the relationship between our new media, popular culture particularly, and the structures of our domination. According to Marx, they who have power control ideas.

Because, our times are not theirs, though many parallels can be found, we must turn to them, who, poison our minds, and make all of our lives unlike they should be. We must turn to them in all areas : no matter if "false intellectuals", or the false idols of our times.

In the times that are ours, and we cannot escape, unfortunately, but they remain at all times the best times, we must bring ourselves to confront what our days offer, and have to offer. "Money and hoes, more money and hoes."

In this case study, we turn to the particular taste- and idea-makers of the constrained, though highly influential, strange, strange world of rappers.
\end{abstract}


"they, who loved them so much, and have betrayed them." (James Baldwin) 


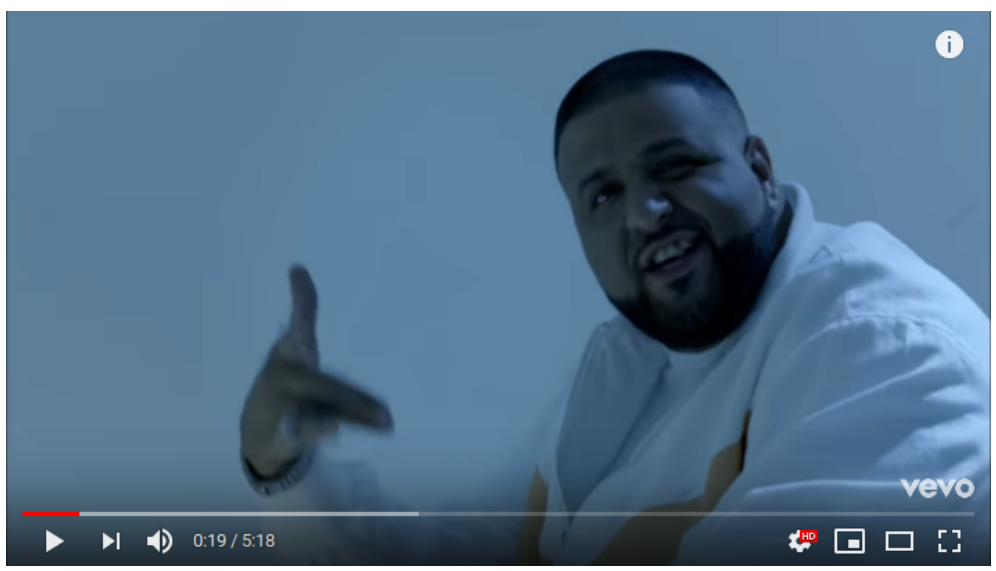

\section{Introduction : slaves vs. "Uncle Tom"'s}

In one of his speeches or writings, Malcolm X posited the existence of two fundamental classes of people (in (our) society) :

The slaves, and what he established as the figure of the "house negro" (elsewhere also "Uncle Tom").

The slaves knew of their oppression at any given moment : so when they worked 16 hour days, when they bled on cotton, when those they loved and cherished with all of their mutilated hearts were made to become "strange fruits" (as Nina Simone heartbreakingly sang), hanging on strange trees, the real not-so "Gentle South".

The "Uncle Tom"'s, Malcolm explains, sat on the porch of their masters, liberated from the hard task of slaves, but contributing to the further imprisonment of those who were, in all ways, and in truth : their fellow men and women, those with the same causes.

They betrayed them so.

We turn here to the new "Uncle Tom"'s of our society, of our times for every generation has their new ones, the ones they deserve, in other domains the false intellectuals we have already described elsewhere, and that Marx and Engels had already described in their days, around the $1860 \mathrm{~s}$ - the peculiar case of rappers, and their peculiar language, and ideals, and falsehoods.

\section{1. "Uncle Tom"s}

"All I care about is money, and the city I am from."

So, sang the musician Aubrey Graham - better known by his artistic handle Drake - around 2011, at the age of 20-something.

His youth excused it, as he explains later in the lyrics of this particular song entitled "I'm On One" (with DJ Khaled, above).

Not much evolution occurred in the case of this singer.

In 2015, in a collaboration with fellow rapper Future, he sang : 
[She] danced all night. Get a plastic bag. Go ahead and pick up all the cash. Go ahead and pick up all the cash.

What a Time to Be Alive indeed. (The song is "Plastic Bag".)

Specks on Tom Ford, button-down Michael Kors. I'd die over these Reeboks, you ain't even know it. Put Molly all in her champagne, she ain't even know it. I took her home and I enjoyed that, she ain't even know it.

(Rick Ross and Future, "U.O.E.N.O".)

"This peculiar language", as James Baldwin had so acutely put it, speaking of the issues of his times, namely the usage of the word "Negro" that was preponderant and contributed to their dominance this peculiar language is that of these "Uncle Tom" rappers.

They have become their own slaves, their own masters - the instruments of their own domination. But, worse, they put shackles - the shackles of the mind that are the worst - on the many, often young, most coming from low socio-economic backgrounds, listeners of their strange doctrines and tenets. Though, not only them.

In 2013, the rapper Jay-Z, who by then had long, long lost touch with the realities of his fellow men and women, released an album entitled Magna Carta Holy Grail that may well go down as the most perplexing piece of art released in this century.

An album, rightly denounced by critics, as what may only be accurately called "an hour-long advertisement".

"Tom Ford", "Picasso", "BBC". But, "Nickels and Dimes" is all he got at the end, as he himself seems to have understood in some abstract way, having placed that song at the end of the album.

His domination was so : he had come to love his masters.

They had come to embrace them, thinking they were a part of them.

In a color-TV interview, that can be considered historic for reasons that have not been stressed enough, a (white) TV presenter asked James Baldwin to speak - as was the custom of the time - about the so-called "Negro cause" and the so-called "Negro Struggle".

But, Baldwin, who like all of the leading intellectuals of his times, the ones he was close to at least, Martin Luther and Malcolm X certainly, as attested by many interviews, used that language, instead started his speech so :

Well, I don't think there's much hope for it. As long, as people are using this peculiar language.

They own us not economically, only, but in this way too : By the language they use, which is theirs, and impose on us. And, we readily reuse.

The secret of Baldwin, they do not know :

And, so we will put it in such a form that will match their language, and, so, even they, who, poison us, will understand :

Nobody messed with Baldwin. 
And, they did not, because James Baldwin spoke in a language so beautiful, so true, and so accurate - sharp as a knife - that even they who considered him inferior based on the color of his skin, knew that to be fundamentally true, equally. And, knew better than to start.

You betrayed him.

You, who should have loved him, and betrayed him so.

Because Baldwin could run circles around any them : no basketball, or raps.

Baldwin - a meteorite fallen from the sky, should have never become what he did become : a boy from the ghetto, who loved school, and was encouraged by his teachers, to become what no one ever could imagine for he became an entirely new kind of human.

His language and intellect made him colorless, purple.

When he was done speaking at Cambridge, he sat down. But, all stood up. He was queer, he was black and purple, he was smarter than the smartest, he was so many things that he should have never become but nonetheless still would.

It should come as no surprise that these same false idols of our times should have - as the singer, actor and civil rights activist Harry Belafonte (a contemporary of Baldwin, who appeared alongside him in many instances of their common fight for common causes) has already noted - the safest of all (possible) political opinions :

Shawn Carter, Jay-Z, and his wife, Beyonce Giselle Knowles-Carter, Beyonce, supported Hilary Clinton ; a figure of the politics of our times - a reflection of them - that to so many represent the epitome of "false" left politics, that is politics "left"-only-in-name, but in nature, their true nature, much better aligned with the centrist politics of our elites, the same that support the status quo that is in their interest, but never is in ours, who are oppressed by these same times, and their circumstances. (They are not)

Drake : we do not know, exactly, he may prefer to appear in the many videos, presenting himself, and to ourselves, a fantasized version of our true lives, and of his, versions that keep us from facing them, as Baldwin had put it.

But, only a pawn in their game. They have learned none of the lessons that their predecessors - their fellow artists even - have left for them. Devoid of any conscience, or consciousness, complicit in their own domination, but worse, complicit in that of others on a mass scale. (That specifically enabled by our new media.)

In concluding this section, we turn to the strangest case of all :

My mama was raised in the era when Clean water was only served to the fairer skin (...) "What you want, a Bentley? Fur coat? A diamond chain? All you blacks want all the same things" Used to only be niggas, now everybody playin' Spendin' everything on Alexander Wang New slaves

Not, a new slave : he'd rather be the black owner on the farm.

I'd rather be a dick, than a swallower. 


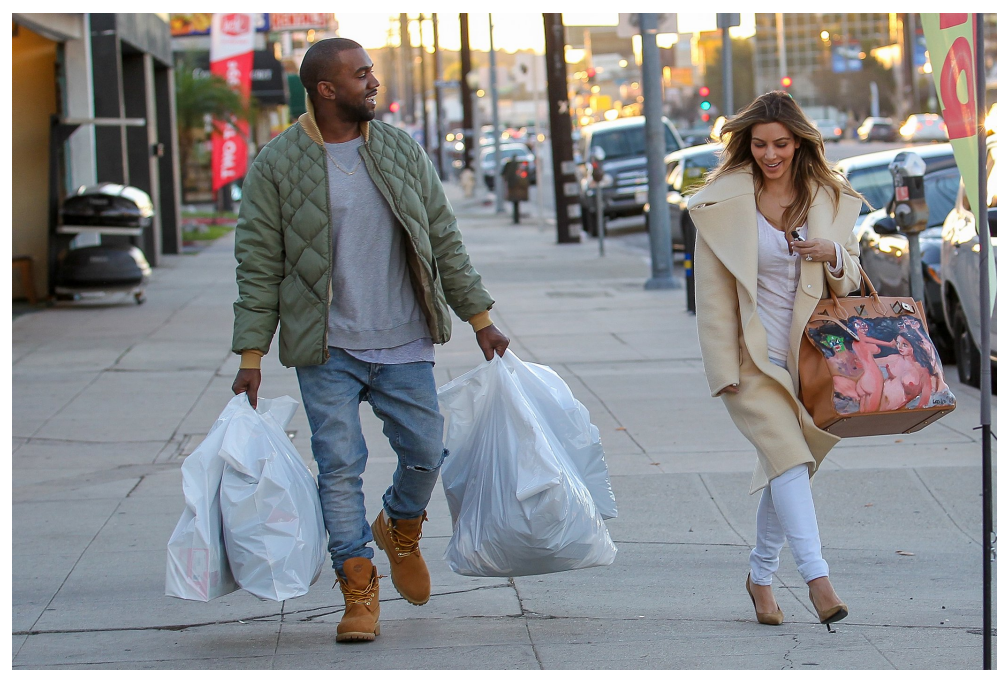

Figure 1: Kanye and wife shopping. (Money 2015)

The modern day equivalent of the old "Chiquita" commercials or "Selling Negroes" videos - we are not sure.

The excrement of our times : we must be ready to muddle with them : for they are the best things of our times, not only passed as different things, but best.

But, worse, it always gets worse :

You remind me of something. I just can't think what it is.

You remind me of my jeep. I wanna ride it. Something like my sounds. I wanna pump it. Girl you look just like my cars. I wanna wax it. And something like my bank account.

So, sang, the one who may be remembered in history as the "original" "Uncle Tom" in the world of singing rappers : the always-gentleman and subtle R. Kelly. (This song is "Your Remind of Me Something", while he reminds us of prison.)

"Material" = woman.

They abuse us with their false ideas, their false ideals, their false language, in many ways : but in the case of this rapper, literally.

Is is why so many of their album covers, imageries seem to reflect a fixation with porches?

\section{The political education, and evolution of New Voices.}

We focus here on a group of artists that came together - they organized - because they presumably saw in each other the same, even when they did not know it, even when they were not quite it - yet.

But, we all must go through our own experiences to become who we are. We render here theirs, who went from rapping about the old 
formula of money+women+cars=success to "the blacker the berry, the sweeter the juice".

At the very start, they were not quite what they have come to be and many of us have come to admire : "Black Hippy". In some ways, it can be said that they had fit the generic stereotype of the rapper, that they wanted them to be, but glimpses :

In his break-out song "A.D.H.D", from his first 2011 album Section 80, Kendrick Lamar, who then went by the diminutive K-Dot, sang :

You know, when you part of Section 80. And you feel like no one can relate. 'Cause you are, you are, a loner, loner. Marijuana endorphins make you stronger, stronger. I'm in the house party, trippin' off. My generation sippin' cough syrup like it's water. Never no pancakes in the kitchen. Man, not one of our lives is caught up.

His fellow artist, Quincy Hanley, better known as ScHoolboy Q, reflected similar nihislitic concerns :

Weed and brews, Life for me is just weed and brews. (...) Let's get stupid high where I can't reply. (...) I love drunk and driving, man I'm something else.

With the same elements of social critic, sometimes hard to distinguish from cinicism and participation (if not pure celebration).

In an album lucidly entitled : Habits \& Contradictions (followed by Oxymoron in 2014).

But, did things change. And, they changed things - the system of their domination, that had only given them only so many possibilities.

"You made me a killer. Emancipation of a real nigger."

So, sang Kendrick Lamar, now transformed, in the much celebrated - from Bowie to The Guardian - 2015 album To Pimp a Butterfly, recorded over a period of three-some years.

In which Kendrick Lamar, can be said to have become himself : The greatest living political rapper of his time.

Everything black, I don't want black (They want us to bow) I want everything black, I ain't need black (Down to our knees) Some white, some black, I ain't mean black (And pray to the God) Once I finish this, witnesses will convey just what I mean You vandalize my perception (...) You made me a killer, emancipation of a real nigga

(Baldwin had famously understood his role as that of a "witness" himself. Contrary to the direct action of Malcolm, the speeches of King, he bore witness : by speaking about them, in his language that was so true and unforgiving, spreading the causes of his times far and wide.) (The spread of information : a condition for organization.)

But, yet another rapper from this group, had shown a way to be "something else" before him, Ab-Soul, who in 2012 already rhymed : 
If all the gangs in the world unified, we'd stand a chance against the military to 9 . Babylon, Babylon, at my window all I see is Babylon; on the news all I see is Babylon. And, all niggas do is just babble on : money and hoes ...

A song that stands as equals with the likes of those of Bob Dylan. Songs for our times, with no embellishments, so we may face them for, and as what they are.

Despair transformed into hope : We laugh when we don't cry.

They emancipated : They organized. 


\section{Conclusion : Bourgeois and Proletarians}

Our rappers are on none of the Billionaires List's - to which they so desperately aspire to belong, in their bottomless quest for materialism. They are given what they can be afforded to be given, by those who are.

They are complicit in their own domination, as some of them have come to know (a knowledge that even dispenses them from action).

But, others have shown us a different way. To be. To be an artist and intellectual in our times. We deserve more like them.

"Freeman and slave, patrician and plebeian, lord and serf, guild-master and journeyman, in a word, oppressor and oppressed, stood in constant opposition to one another, carried on an uninterrupted, now hidden, now open fight, a fight that each time ended, either in a revolutionary reconstitution of society at large, or in the common ruin of the contending classes." (Communist Manifesto)

By killing our real idols, they do worse :

They killed them. And, made us killers too.

They rob us in that way too. 


\section{Bibliography}

Baldwin, James. "Remember This House" (unfinished). Published as : - 2017. I Am Not Your Negro.

Peck, Raoul. 2016. I Am Not Your Negro. [documentary]

Kendrick, Lamar. 2015. To Pimp a Butterfly.

Kendrick, Lamar [K-Dot]. 2011. Section 80.

Ab-Soul. 2012. Control System.

Hanley, Quincy [ScHoolboy Q]. 2012. Habits \& Contradictions

Kelly, Robert [R. Kelly]. 1995. R. Kelly.

Description : the "original" "Uncle Tom".

Carter, Shawn [Jay-Z]. 2013. Magna Carta Holy Grail.

Description : the new "Uncle Tom", owner of himself.

West, Kanye [Kanye West]. 2013. Yeezus.

Description : a mystery to everyone and probably himself.

Poppick, Susie. 2015. "The 5 Best Money Quotes..." Money, 21/06.

Description : read Baldwin instead.

\section{Superstructure and base structure}

These various artists represent not only opposite models, conceptually, but are, including in their structures, organized around different networks of people, organizations : labels, (new) owners, etc. 